Carola Trips*

\title{
Impersonal and reflexive uses of Middle English psych verbs under contact influence with Old French
}

https://doi.org/10.1515/lingvan-2019-0016

Received February 16, 2019; accepted June 14, 2019

\begin{abstract}
This article discusses the relation between impersonal constructions and the reflexive use of psych verbs of the admire-type (Levin 1993) copied from Old French to Middle English. The outset of the study is an observation made by van der Gaaf (1904) which was commented on by Fischer (1992) concerning the reflexive use of verbs like remembren (Old French remembrer) in the course of the development of impersonal constructions to personal constructions. My aim is to answer the following questions: First, was the reflexive use of verbs copied from Old French new to the Middle English system? Second, what is the syntactic and semantic relation between ME impersonal and OF reflexive constructions? I will first examine the reflexive construction in Old English and Old French to answer the first question. I will then deal with the second question taking a closer look at both constructions in Middle English. Supported by lexicon-based and corpus-based small-scale studies of the psych verb remembren I will provide an analysis of the syntactic and semantic properties of the verb in both constructions and show that what they have in common is an intransitive structure where the subject is an EXPERIENCER, and middle semantics. I will finally address possible effects of language contact through translations, before I conclude.
\end{abstract}

Keywords: Middle English; Old French; argument structure; Psych verbs; Reflexives

\section{Introduction}

This article discusses the syntactic and semantic relation between the reflexive use and the impersonal construction of psych verbs of the admire-type (Levin 1993) copied from Old French ${ }^{1}$ (OF, 842-1220). I will further examine whether these instances of reflexive use have played a role in the rise of the reflexive system in the history of English. This small-scale study is part of a bigger project examining whether the grammatical system of Middle English (ME, 1150-1500) was influenced by the copying of OF verbs and if so, to what extent it affected the argument structural properties of the native system. ${ }^{2}$

Instead of using the more traditional and more problematic term 'borrowing' I will use Johanson's (2002: 287f) term copying as it allows for the non-identicality of original and copied material. Further, I will assume that verbs copied from OF to ME are global copies in Johanson's terms, bringing along a block of properties (material, semantic, combinational in syntax and word structure, frequential).

The outset of the present study is an observation made by van der Gaaf (1904: ch.5): in his monograph on the development of the impersonal construction in ME he noted that verbs copied from OF are found both in

1 For the sake of simplicity I will use Old French as a cover term for varieties of French spoken/written at the given time like continental Old French and Anglo-Norman (cf. Trips and Stein 2019).

2 The project Borrowing of Argument Structure in Contact Situations (BASICS) is funded by the Deutsche Forschungsgemeinschaft, DFG research grant TRI555/6-1, TRI555/6-2 Sachbeihilfe. For further information see https://tinyurl.com/dfgbasics/.

*Corresponding author: Carola Trips, Universitat Mannheim, Anglistik IV, B 6, 30-32, Mannheim 68159, Germany, E-mail: ctrips@mail.uni-mannheim.de 
the reflexive use and in the impersonal construction. The examples in (1) illustrate the former. ${ }^{3}$ The example in a. is the first attestation of the ME psych verb remembren in the Middle English Dictionary (MED, McSparran et al. (2000-2018)). The examples in b. and c. show the reflexive use of the verb “... in 14th century English, just as in O. F.” (van der Gaaf 1904: 144).

(1) a. pe seuen holy gostes lowen hem whan pai remembren hem of [vr.how] pat Iesus The seven holy ghosts love them when they remember them.RFL of that Jesus Crist suffred.

Christ suffered

(MED, c1350 Apoc.(1) in LuSE (Hrl 874) p.42)

b. A man shal remembre him of hise sinnes

a man shall remember him.RFL of his sins

c. I wol remembre me alle the yeres of my lyf

I will remember me.RFL all the years of my life

(Chaucer, Cant. T. I 133, in van der Gaaf (1904:144))

Example (2) is an instance of the impersonal use exhibiting the typical pattern of a non-nominative subject and the third person singular default form of the verb.

(2) At euery tyme that me remembreth of the day of dome, I quake.

at every time that me.IMP remember.3SG of the day of doom, I quake

((c1390) Chaucer CT.Pars. (Manly-Rickert) I.159 in van der Gaaf (1904:145))

Fischer (1992: 237) comments on van der Gaaf's observations and states that the origin of these verbs "cannot be a coincidence". She assumes that “... there was felt to be a relation between impersonal constructions and these French reflexive constructions" (p. 238). She explains this by stating that ME speakers/writers were not familiar with, as she calls them, the 'pure reflexives' which French exhibits. This is, as she claims, because in Old English (OE, ca 800-1150) 'reflexive' pronouns had their own semantic role whereas in OF they did not. She illustrates this difference with the following examples: $a$. is from OE and b. and c. are two of van der Gaaf's ME examples cited above: ${ }^{4}$

(3) a. And pa Pyhtas heom abædon wif æt Scottum

and the Picts them. $[+\mathrm{TH}]$ asked-for wives at Scots

'And the Picts asked for wives for themselves from the Scots'

(Chron.B(Plummer)15 in Fischer 1992:238)

b. A man shal remembre him of hise sinnes

a man shall remember him.[-TH] of his sins

'A man shall remember his sins.'

(Chaucer, Cant. T. I 133 in Fischer 1992:238)

c. At euery tyme that me remembreth of the day of dome, I quake. at every time that me.[+TH] remembereth of the day of doom, I quake 'Every time that I remember the day of doom, I quake.'

In the OE example in a. the 'reflexive' pronoun has a semantic role, whereas in the ME example in $\mathrm{b}$. with the psych verb copied from OF it does not. In the example in c. displaying the impersonal construction with this verb the argument $m e$ has a semantic role as well. Fischer remarks that "[i]t must have been difficult to fit the Old French pure reflexives into the grammar of Middle English ...”. I take this to imply that the two

3 RLF marks reflexive use, IMP marks impersonal use.

4 I added the feature [+/-TH] (theta) to mark the presence/absence of a semantic/thematic role. 
systems were in conflict and ME speakers/writers sought a way to syntactically and semantically "adjust” the French type reflexive to the ME system, possibly by way of using the established impersonal construction. Whereas the reflexive system as we know it today developed in the course of the ME period, the impersonal construction was lost by the end of that same period (e.g. Allen 1995: 450).

In the syntactic literature on the English impersonal construction there is no consensus as to what “impersonal” refers to (see e.g. Sweet 1891; Fischer and van der Leek 1983; Denison 1990; Allen 1995; for other Germanic languages see Barðdal 2004). Scrutinising the various definitions found, Möhlig-Falke (2012: 12) proposes the following two criteria to define impersonalhood that I will use in this article:

Criterion A: the lexical finite verb is invariably marked for 3SG.

Criterion B: a noun phrase or pronoun in the nominative singular that could formally control verbal agreement is absent.

Of the seven basic patterns that express the impersonal construction the most common one is the transitive one where the first argument is (pro)nominal marked accusative or dative and the second argument is a (pro)nominal marked genitive, a prepositional complement, or a (non)finite complement clause. Two examples of this type are given in (4):

(4)

a. $\begin{aligned} & \text { men sceamad for godan } \\ & \text { men.ACC.DAT.PL feel shame.3sG for good.ACC.DAT.PL deed.ACC.DAT.PL than for }\end{aligned}$
for $\quad$ yfelan $\quad$ dædan
evil.ACC.DAT.PL deed.ACC.DAT.PL

'men are more ashamed of good deeds than of evil deeds'

(WHom 20.1 [0031 (103)] in Möhlig-Falke 2012: 7)

b. ðи goda cyningc licað ðe well pat Appolonius ... pus you.NOM.SG good.NOM.SG king.NOM.SG like.3SG you.ACC.DAT.SG well that Appolonius thus heonon fare.

from here go

'good King, does it please you well that Appolonius ... departs from-here thus ...?

(ApT (0179 (17.22)] in Möhlig-Falke 2012: 7)

The following four developmental paths of the impersonal construction have been identified (Möhlig-Falke 2012: ch.1): first, verbs that exhibited the impersonal use were lost (e.g. ME thinken 'seem, appear'); second, the expletive (h)it was inserted (e.g. hit likede the lordes) which rendered the constructions personal; third, the acc/dat argument was reinterpreted as a nominative subject (me liketh sth. $\rightarrow$ I like sth.); fourth, in some cases a copula construction superseded an impersonal construction (me hungered $\rightarrow I$ am hungry).

Ogura (2003) has shown that a small set of OE verbs occur in the reflexive use as well as in the impersonal construction and claimed that both constructions have the function of a middle voice marker that English lacks, which implies that both seem to share the same semantic properties. ${ }^{5}$ In Section 4 I will more closely examine the syntactic and semantic properties that this construction has in common with the reflexive use in Early English.

To my knowledge there is hitherto no study which has taken a closer look at van der Gaaf's observation and Fischer's (rather sketchy) analysis by comparing the reflexive systems of ME and OF and by taking contact-induced change on the level of argument structure into account. Moreover, there is no study which examines the role that psych verbs copied from OF might have played in the loss of the impersonal construction, and the rise of reflexives; even Möhlig-Falke's (2012) seminal work only marginally mentions

5 Unfortunately, Ogura only mentions this without providing any analysis at all. 
OF influence (ch. 7). Thus, to shed some light on these aspects I seek to answer the following questions:

Question 1: Was the use of 'reflexive' pronouns lacking a semantic role new to the ME system?

Question 2: What is the syntactic and semantic relation between ME impersonal constructions and OF reflexive constructions?

In the following section I will provide a classification of reflexives that I will then apply to the data discussed by van der Gaaf and Fischer, i.e. to the psych verb remembren. In Section 3 I will compare the reflexive systems of $\mathrm{OE}$ and $\mathrm{OF}$ and apply the classification introduced in Section 2. On this basis I will provide an answer for Question 1. Section 4 deals with the rise of the reflexive system and the loss of the impersonal construction in ME. On the basis of a small-scale lexicon-based and corpus-based study of the verb remembren and its OF source remembrer, which I will later extend to further psych verbs of this type, I will propose an analysis that answers Question 2. I will also briefly discuss some examples from the text Ayenbite of Inwyt in the light of language contact through translation. Section 5 summarises my findings and concludes the article.

\section{Classifying reflexives}

Before I discuss the classification of reflexives used in this article, I would like to point out that I do not subscribe to one particular framework for my analysis of the data. Rather, I will use classifications and models that, in my opinion, fit the research questions and data best.

In a very general sense a predicate can be called 'reflexive' whenever two of its arguments refer to the same person, i.e. when they are co-referent. This definition makes no reference to the linguistic means used to express it (cf. Waltereit 2012: 12) but generally the element that indicates co-reference is called reflexive marker (or reflexive pronoun). Depending on the language, reflexive markers can be a productive grammatical device to mark reflexive situations. According to Kemmer (1993: 48), Present-Day English is a language which uses the set of self-pronouns to mark all three persons in reflexive situations (as well as the adnominal intensifier, see König and Siemund 2000). These forms inflect for person, number, and in the third form, for gender. In contrast, the systems of French and German use the first and second person pronouns to mark co-reference and have an invariable third person reflexive marker (se, sich). Thus, formally the English, and the French and German systems are quite different. I will come back to this point below.

Next, I will introduce the classification of reflexives used here to analyse differences between reflexive interpretations in OE, OF and ME. I will make use of Steinbach's (2002: 3) differentiation between the reflexive and the inherent reflexive interpretation because it serves well to illustrate the difference that Fischer (1992) addresses. The former type is illustrated with the German example in (5) and schematised in (6).

(5) Herr Rossi rasiert sich

Mr. Rossi.nOM shaves reflexive-pronoun.ACC

'Mr. Rossi is shaving (himself)'

(6) c-selection: NP-SBJ RFL

s-selection: $\quad \begin{array}{lll} & \downarrow & \downarrow \\ & & \end{array}$

In German sich functions as a reflexive marker (third-person only). In the reflexive interpretation, the reflexive pronoun is both c(ategorially)-selected and s(emantically)-selected and therefore interpreted as a semantic argument of the verb, bound by and co-referent with the subject. ${ }^{6}$ Thus, the subject Herr Rossi and

6 Following Steinbach (2002) I will use the terms c-selection and s-selection without implying any theoretical stance. 
the accusative object sich are linked to a semantic argument variable of the verb. This is not the case in the inherent reflexive interpretation illustrated in (7) and schematised in (8).

(7) Herr Rossi erkältet sich

Mr. Rossi.nOM catches-a-cold reflexive-pronoun.ACC

'Mr. Rossi catches a cold'

(8) c-selection: NP-SBJ RFL

s-selection: $\quad \begin{array}{lll} & \downarrow & \downarrow \\ & \mathrm{x} & \emptyset\end{array}$

In this case the reflexive pronoun sich is only c-selected but not s-selected. Therefore it is not interpreted as a semantic argument of the verb. The difference becomes apparent when we take a look at the distribution of sich in these two cases: In the first case (Herr Rossi rasiert sich) it has the same distribution as a personal pronoun, and this is why we can also say Herr Rossi rasiert mich/ihn 'Herr Rossi is shaving me/him'. This cannot be applied to the sentence with the verb erkälten ( ${ }^{*}$ Herr Rossi erkältet mich/ihn). The crucial difference is that the reflexive interpretation is a two-place predication whereas the inherent reflexive interpretation is not; due to argument reduction it is a one-place predication (derived from a two-place predication, cf. Steinbach 2002: 4; this type of reflexive verb is also called inherent anticausative reflexive, cf. Steinbach 2002: 232). This difference is captured in Steinbach's terms 'argument reflexive' and 'non-argument reflexive' that I will use in the following sections for my analysis. ${ }^{7}$

If we apply this classification to the data Fischer discussed, we find the same contrast. The OE example schematised here in (9) receives a reflexive interpretation, the personal pronoun heom used as a reflexive marker with the verb abiddan 'to ask for sth.' is both c-selected and s-selected, i.e. it is interpreted as a semantic argument (argument reflexive).

(9)

$\begin{array}{lccc} & \text { pa Pyhtas } & \text { heom } & \text { abædon wif æt Scottum } \\ \text { c-selection: } & \text { NP-SBJ } & \text { RFL } & \\ & \downarrow & \downarrow & \\ \text { s-selection: } & \mathbf{x} & \mathbf{y} & \end{array}$

In the example with the verb remembren schematised in (10), however, the reflexive marker him is c-selected but not s-selected, i.e. it is not a semantic argument (non-argument reflexive). The translation into Present-Day English makes this clear: in 'A man shall remember his sins' (meaning 'recall to mind', cf. Fellbaum 1998), the object (reflexive pronoun) is not needed. This is possible because psych verbs like remembren/remember denote a mental state that is directed at one's self. ${ }^{8}$

(10)

$\begin{array}{lccc} & \text { A man } & \text { shal remembre } & \text { him of hise sinnes } \\ \text { c-selection: } & \text { NP-SBJ } & \text { RFL } \\ & \downarrow & \downarrow \\ \text { s-selection: } & \mathrm{x} & \emptyset\end{array}$

From these few examples it seems that OE reflexive constructions are argument reflexives whereas in ME non-argumental reflexive constructions existed, at least with verbs copied from OF like remembren. This will be further explored in the next section.

7 Steinbach also calls the latter inherent anticausative verbs.

8 van Gelderen (2018: ch.6) discusses the development of psych verbs and notes that only object-EXPERIENCER verbs (Levin's amuse-type verbs) are causative. The admire-type psych verbs under investigation are subject-EXPERIENCER verbs and lack this property. 


\section{A comparison of reflexive constructions in Old English and Old French}

\subsection{Old English}

This section introduces the reflexive systems of OE and OF by taking a look at both the formal (morphological) expression and semantic interpretation of reflexivity. Against this background I will examine whether all reflexive uses in $\mathrm{OE}$ were of the argument type, which would corroborate Fischer's assumption discussed in Section 1.

Consulting Keenan's (2009) article on the historical creation of English reflexives quickly falsifies Fischer's assumption. First, Keenan notes that in OE (local) binding is generally established with personal pronouns which is illustrated with the examples in (11).

(11) a. ða gegyrede heo hy mid hærenre tunecan then dressed she $_{\mathrm{i}} \cdot \mathrm{NOM}$ her $\mathrm{i}_{\mathrm{i}}$.ACC with of-hair tunic 'then she dressed herself in a tunic of hair.'

(Mart 190 c.875 in Keenan 2009:20)

b. forðæm hi him ondrædaðða frecenesse ðе hi ne gesioð because they $_{\mathrm{i}}$-NOM them ${ }_{\mathrm{i}}$.DAT fear the danger that they NEG see

'because they fear the danger that they do not see.

c. se Hælende sealde hine sylfne for us the $\operatorname{lord}_{\mathrm{i}}$.NOM.SG.M gave him $_{\mathrm{i}}$.ACC.SG.M self.ACC.M.SG for us 'The Saviour gave himself for us.'

Concerning the types of reflexive interpretation, argument reflexives as well as non-argument reflexives exist, the latter of which Keenan calls 'pleonastic pronouns' (Keenan 2009: 20, in line with others, e.g. Möhlig-Falke 2012: 187; Peitsara 1997: 278; van Gelderen 2002: 27ff). Two clear cases are (11) a. with the verb ge-gyrdan 'to gird' and b. with the admire-type psych verb on-drædan 'to fear', respectively. Furthermore, self functioned as an intensifier and could be combined with a personal pronoun in object position (co-reference with preceding subject) as the example in c. with the verb sellan 'to give' illustrates (see König and Siemund 2000). We can conclude that at the time English speakers/writers were exposed to French (psych) verbs used reflexively, argument and non-argument reflexives had already been part of their native inventory.

\subsection{Old French}

In OF there are various ways to formally express reflexivity. First of all, reflexive morphemes (clitics) exist which can be interpreted as expressing a participant of the event or not (for a discussion see Waltereit 2012: ch4). According to the terminology used here, they can be either argument or non-argument reflexives. Heidinger (2010: 47) states that with psych verbs reflexive morphemes do not have a semantic role (nonargument reflexives). Two examples with psych verbs given in (12) (se merveiller 'to marvel', se corrocier 'to get angry') illustrate this type of reflexive interpretation:

(12) a. N'i ait Franceis ki tot ne s'en merveilt. no-there has Frank that totally not RLF.of-it wondered 'That there was no Frank that was not astonished because of that.' (Rol: verse 571, in Heidinger 2010:42) 
b. A moi s'est Deus coreciez.

over me RFL.is god angry

'God became angry over me'.

(Gui: verse 890, in Heidinger 2010:47)

Another way to express reflexivity in OF is achieved by using the stressed reflexive pronoun soi. It was widely used to establish co-reference with any singular subject, and it more often occurred in argument position (argument reflexive). The example in (13) exhibits the use of soi as an argument, co-referential with the (null) subject.

(13) Devant soi voit ses enemis.

before REFL see.3SG Poss enemies

' $\mathrm{He}_{\mathrm{i}}$ see his enemies in front of himself $\mathrm{i}$ '.

(Waltereit 2012:2)

Further, the personal pronouns lui/elle/eux/elles could be used to establish a reflexive interpretation, and they were either semantic arguments or not. In the literature, it is stated that they more frequently occur in adjunct (non-argument) position. (14) displays such a case (again with a null subject).

(14) Entour lui mete son mantel.

around him put.3SG Poss coat

'He ${ }_{\mathrm{i}}$ puts his coat around his $\mathrm{i}_{\mathrm{i}}$ shoulders.'

(Waltereit 2012:2)

Concerning the development of the reflexive system in French, the stressed reflexive pronoun soi was largely replaced by the personal pronoun (cf. Waltereit 2012: 3). This applies to the third person only. ${ }^{9}$ This change is opposed to what happened in English where personal pronouns have gradually given way to the specialised compound reflexive (himself etc., see below).

Having surveyed the reflexive systems of OF and OE I am now in a position to answer Question 1 (Was the non-argument reflexive new to the ME system?): Contra Fischer's assumption, we have seen that in OE the argument reflexive as well as the non-argument reflexive interpretation was part of the grammatical system. ME speakers/writers confronted with the OF system were familiar with both types. This may be seen as a favouring factor in the copying of OF verbs following Winford (2003: 51ff). The formal expression of reflexivity was quite different, however. Although both languages could use personal pronouns to mark reflexivity, OF also had the invariable third person reflexive marker (clitic) se which OE completely lacks. This may have led speakers/writers to seek alternative ways to copy/translate OF reflexive uses (see Section 4). A more comprehensive study would need to address this issue more thoroughly.

\section{Reflexive and impersonal constructions in ME}

In this section, I will examine the reflexive uses and the occurrence of the impersonal construction in ME. I will discuss findings from a lexicon-based and corpus-based study of admire-type psych verbs and provide an answer to Question 2.

We have seen that in $\mathrm{OE}$ the reflexive use of verbs was generally expressed by a personal pronoun, a reflexive marker did not exist (see also Mossé 1991: §120). The personal pronoun as a 'reflexive marker' either had argument status or not. In addition, the intensifier self could be combined with a personal pronoun in object

9 Due to space limitations I cannot provide a full comparative analysis of the OF and OE/ME systems here which would have to include the difference between argument/non-argument as well as +/- reflexive. 
position to indicate emphasis or contrast (see e.g. Visser 1963: §159,§426; Peitsara 1997: 297; van Gelderen 2002). In ME, the intensifier occurs more and more often in compound forms (himself, herself etc.; cf. König and Siemund 2000: 46), which leads to a situation where two alternative ways to express reflexivity compete with each other (cf. Peitsara 1997: 280). In the course of the ME period, the paradigm of reflexive pronouns developed disambiguating the reflexive use of verbs (cf. also van Gelderen 2002; McWhorter 2004; Keenan 2009). Some authors attribute this development to French influence: Einenkel (1916: §50); Mustanoja (1960: 502-3) and Visser (1963: §328) assume that these constructions are calques of French expressions or built in analogy to French reflexive verbs.

In her study of the Helsinki Corpus (Matti Rissanen et al. 1991), Peitsara (1997) investigates the reflexive strategies in ME and Early Modern English (EModE) and finds an increase of overtly reflexive constructions in ME with a peak in the subperiod of ME3 (1350-1420) (see Figure 1):

She comments on this finding: "It could be supposed that the peak of frequency in ME3 might have to do with the grammaticalization of the reflexive construction in English but, interestingly enough, it also coincides with the period of most profuse introduction of French vocabulary into English" (Peitsara 1997: 287). Describing the data, she finds that the verbs copied from OF are mainly abstract verbs, many from the field of social behaviour as well as psych verbs of various kinds. Crucially, these verbs all exhibit the 'simple strategy', i.e. the reflexive use of the personal pronoun which, as she observes, “... would really require no object at all" (1997: 302), for example I assente me, quod I 'I agree, said I' (Chaucer, Boethius 434.C2). This is in line with what I stated in Section 2 about the nature of psych verbs: both remembren and assenten are verbs of mental experience which are directed at one's self (the subject argument) which implies a one-place predication. To gain further insight into the role OF possibly played in the rise of the reflexive system in ME, we need to see which argument structural properties OF verbs had that may have been copied to ME, i.e. a comparative study is in order. Therefore, I will provide data from small-scale lexicon-based and corpus-based studies of the OF verb remembrer and its ME equivalent remembren.

The main argument structures of the OF verb which were extracted from the Tobler-Lommatzsch: Altfranzösisches Wörterbuch (Blumenthal and Stein 2002) are presented in Table 1:10

I will focus on the two argument structures for the reflexive use (de lui tu ne te remembres ... 'You do not remember him') and the impersonal use (e.g. Donc li remembret de son Seinor celeste 'then he remembers his heavenly Father'). The reflexive use shows the same pattern that is found in ME apart from differences in word order. The second case shows the impersonal use in OF which typically involves an empty subject

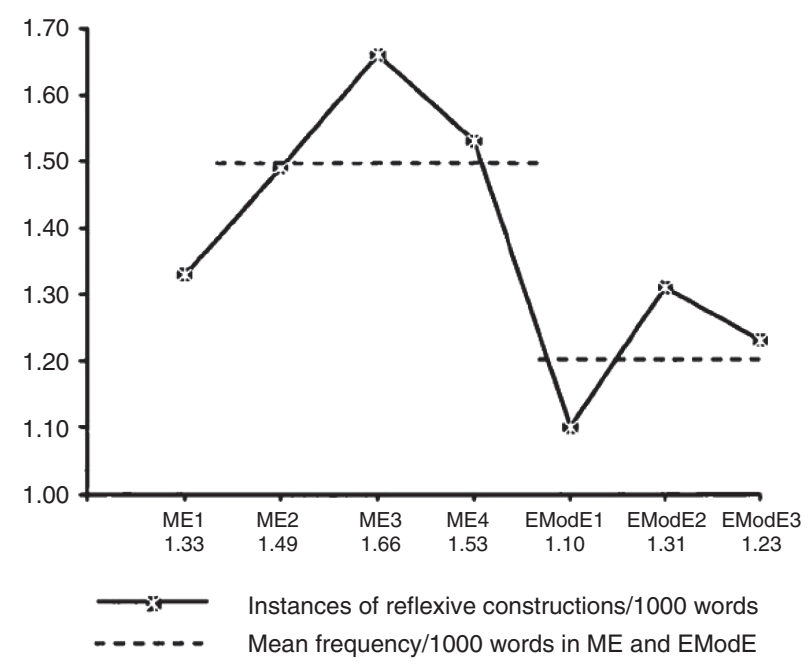

Figure 1: Frequency of overtly reflexive constructions per 1000 words (From Peitsara 1997: 288).

10 I kept the original German descriptions of the verb. 
Table 1: remembrer in the Tobler-Lommatzsch (TL)

\begin{tabular}{llll}
\hline remembrer (TL) & trans. & (wieder) in Erinnerung bringen & Si com li contes nos remembre (Ombre 24) \\
\hline & refl. & sich erinnern an & $\begin{array}{l}\text { de lui tu ne te remembres Fors quant en veulz aucun mal dire } \\
\text { (Gace de la Buigne 2810) }\end{array}$ \\
& intrans. & sich erinnern an & $\begin{array}{l}\text { De ton peire dois remenbrer Que jones fut et valés biaus } \\
\text { (Florimont 942) } \\
\end{array}$ \\
& subjektlos & (il) me remembre & Donc li remembret de son Seinor celeste (Alex 12b)
\end{tabular}

Table 2: remembren in the OED/MED

\begin{tabular}{|c|c|c|c|}
\hline \multicolumn{4}{|l|}{ OED/MED } \\
\hline \multirow[t]{7}{*}{ remembren } & trans. & To think of, recall the memory of (a person) & a1382 Bible (Wycliffite, E.V.) (Douce 369(1)) \\
\hline & & with some kind of feeling or intention. & (1850) Isa. Ixii. 6 zee that remembren [a1425 \\
\hline & & & $\begin{array}{l}\text { L.V. thenken on; L. reminiscimini] the Lord, ne } \\
\text { beth stille, and ne zyueth scilence to hym }\end{array}$ \\
\hline & intrans. & To have a memory or recollection. & $\begin{array}{l}\text { a1393 Gower CA(Frf 3) 1.2682:The proude vice } \\
\text { of veine gloire Remembreth noght of purga- } \\
\text { toire. }\end{array}$ \\
\hline & refl. & to think about or reflect on (oneself) with some & c1390 Chaucer Parson's Tale (Hengwrt) (2003) \\
\hline & & kind of feeling or intention & $\begin{array}{l}\S 61 \text { I wol remembre me alle the yeris of my lyf } \\
\text { in bitternesse of myn herte. }\end{array}$ \\
\hline & impers. & $\begin{array}{l}\text { To think of, recall the memory of (a person) } \\
\text { with some kind of feeling or intention. }\end{array}$ & $\begin{array}{l}\text { C1390 Chaucer CT.Pars.(Manly-Rickert) I.159: } \\
\text { At euery tyme that me remembreth of the day } \\
\text { of dome, I quake. }\end{array}$ \\
\hline
\end{tabular}

position that is filled by an argument in the dative (or accusative). ${ }^{11}$ If we compare the argument structures for ME remembren found in the Oxford English Dictionary (OED) and the MED we see that the copied verb syntactically realises the same structures as its OF counterpart (see Table 2):

A study of the ME verb in the lemmatised ${ }^{12}$ version of the Penn-Helsinki Parsed Corpus of Middle English Prose (PPCME2) confirms this. Some examples from the corpus are given below.

(15) a. transitive:

... he remembryd $\left[_{N P}\right.$ his blessyd passhyon];

he remembered his blessed passion

'... he remembered his blessed suffering.'

(EDMUND,168.160)

b. ditransitive with an EXPERIENCER as PP:

And thanne God remembrith [ $P$ to hem] [ ${ }_{N P}$ many grete synnis],

and then God remembers to them many great sins

'And then God reminded them of many great sins.'

(PURVEY,I,6.175)

c. intransitive:

bi whiche thei schulden remembre, ...

by which they should remember

'by which they should remember ...'

(OTEST,16,40N.764)

11 In this example, the dative pronoun li fills the empty subject position and expresses the subject of the sentence. For more information on the impersonal construction in OF see Buridant (2000: §320), for a (generative) analysis see Mathieu (2006). Note that the definition of these constructions in OF does not match the one for the OE impersonal construction given in Section 3.

12 For details see Percillier 2018. 
d. reflexive:

scarsly may he shryven hym or remembre $\left[_{N P}\right.$ hym $]\left[_{P P}\right.$ of his synnes] or repenten hym, for the scarsely may he confess him or remember him of his sins or repent him for the grevous maladie of his deeth. grievous malady of his death.

'scarcely may he confess or remember his sins or repent of the grievous disease of this death.'

e. impersonal:

At euery tyme that me remembreth of the day of dome, I quake. at every time that me remembers of the day of doom, I quake

"Every time that I remember the day of doom I shiver;"

(CTPARS,291.C1.106)

From a quantitative point of view the reflexive argument structure is the most frequent one; in a total of 27 tokens it occurs 17 times (with an object pronoun). The impersonal use is only marginal (1/27). Table 3 presents all argument structures found in the corpus with remembren.

According to the analysis discussed in Section 2, the valency slot for the second semantic argument of the reflexive construction is zero since the reflexive use of remembren is non-argumental. If we compare the structure of the reflexive uses with the structure of the impersonal construction, we see that both constructions have the same argument structure: there is one EXPERIENCER argument which functions as the subject of the sentence (compare line 3 and 5 in the table). Syntactically this is the core of the structure needed to express the emotional state of remembren meaning 'recall to mind' as it is directed at one's self. Therefore, we can use an intransitive argument structure in Present-Day English: I remember (see above). So the meaning of this psych verb is expressed by an argument structure that is intransitive in nature ${ }^{13}$ and this is what the reflexive and the impersonal construction have in common used with this type of verb.

I mentioned in Section 3 that Ogura (2003) assumed that the set of OE verbs showing both the reflexive and the impersonal use share the same semantic properties. In Möhlig-Falke's (2012) study only OE verbs belonging to the domain of EMOTION also occurred with reflexive uses. This alternation was extended to a number of verbs in ME, most of them verbs of mental experience (see below). Following Ogura, Möhlig-Falke (2012: 189) argues for an analysis where both the impersonal construction and what I called here the nonargument reflexive (which she calls 'middle reflexive') share middle semantics. Based on Kemmer's (1993) cognitive-functional approach to middles she assumes that the relationship between the participants in a sentence can be described as an action chain with an initiator and an endpoint (see also Langacker 1987, Croft 1991). In a prototypical transitive sentence a dynamic process is directed from a controlling participant (initiator, AGENT) to an affected participant (endpoint, PATIENT). In a middle event the two poles of initiator

Table 3: remembren in the PPCME2

remembren in the lemmatised PPCME2

\begin{tabular}{rllllllrr}
\hline & & Val-slot 1 Syn & Val-slot 1 Sem & Val-slot 2 Syn & Val-slot 2 Sem & Val-slot 3 Syn & \multicolumn{2}{l}{ Val-slot 3 Sem } \\
\hline 1 & ditrans. & NP & AGENT & to-PP & GOAL & NP & THEME & 1 \\
2 & trans. & NP & EXPERIENCER & NP & STIMULUS & & 7 \\
3 & refl. & NP & EXPERIENCER & NP-rfl. & $\emptyset$ & & 11 \\
4 & refl. & NP & EXPERIENCER & NP-rfl. & $\emptyset$ & of/upon-PP & THEME & 6 \\
5 & impers. & NP-pro & EXPERIENCER & & & of-PP & THEME & 1 \\
6 & intrans. & NP & EXPERIENCER & & & & 1 \\
& TOTAL & & & & & & 27 \\
\hline
\end{tabular}

13 The lexical-semantics of the verb includes the knowledge that is recalled which can be syntactically expressed by an argument in object function. As a result we find transitive and even ditransitive structures. For further discussion see the section on unexpressed object alternations in Levin (1993: ch.1.2). 
and endpoint are conflated in a single participant “... as it takes place wholly within the primary participant, who is both the initiator and the endpoint of the process" (Möhlig-Falke 2012: 70). According to Kemmer, the lexical semantics of some verbs are more liable to occur in middle-voice patterns, for example verbs denoting mental experiences since the EXPERIENCER has properties of both initiator and endpoint.

I adopt this cognitive semantic analysis as it complements my formal analysis well and makes clear what the reflexive use and the impersonal construction with admire-type psych verbs have in common. Thus, I can provide an answer to Question 2 (What is the relation (then) between ME impersonal constructions and OF reflexive constructions?): Although the surface syntactic representation of ME I remembre me and me remembreth differ, semantically they do not. Both have the subject-EXPERIENCER as one single participant and can be seen to share middle semantics.

To find further support for my analysis I examined all verbs occurring in the impersonal construction in the lemmatised PPCME2, where searching for French and non-French verbs is possible. For verbs of nonFrench origin I found 80 tokens and 7 types (reuen 'to regret', listen 'to desire', liken 'to be pleased', misliken 'to be displeased', ofthinken 'to be displeasing', shamen 'to feel shame', longen 'to yearn'). For verbs of French origin I found 12 tokens and 7 types (deinen 'to seem worthy', suffisen 'to be adequate', repenten 'to feel regret', remembren 'to reflect', merveillen 'to be filled with wonder', douten 'to feel uncertain', coveiten 'to desire'). Crucially, all of the verbs exhibiting the impersonal construction in the corpus have EXPERIENCER-subjects, i.e. they are admire-type verbs. ${ }^{14}$ This is why we can expect to find them in both constructions. In (16) to (19) I give some examples which confirm this (the a. examples show the impersonal construction, the b. examples the reflexive use).

(16) a. Ah pe schulde scheomien. pu scheomelese schucke. ah thee should shame you shameless devil

'Ah, you should be ashamed, you shameless devil.'

(MARGA,66.169)

b. And pat noman scholde schame him to schewen him such as god made him, and that no man should shame him to show him such as god made him 'and that no one should be ashamed to show him just as god made him.'

(17) a. Himm reowebp off hiss azhenn woh \& off hiss azhenn sinne, him regrets of his own woe and of his own sin

'He regrets his own wretchedness and his own sin.'

b. Mann ... ne rewe him nauht ane hise sennes, man NEG regret him not one his sins

'Man does not only regret his sins ...'

(18) a. "Me merueylyth mech of pis woman why sche wepith so." me marvels much of this woman why she weeps so

'I wonder much about why this woman weeps so.'

b. And for-thi I meruell me pe more, and therefore I marvel me the more 'and therefore I am even more puzzled.' 
(19) a. "me repentis sore the dethe of thys knyght for the love of thys damesel," me repents painfully the death of this knight for the love of this damsel

'I painfully regret the death of this knight for the love of this maiden.'

b. \& pan he repentyd hym pat he had not don aftyr hir cownsel. and then he repented him that he had not done after her counsel 'and then he regretted that he had not acted according to her advice.'

Due to a number of (morpho)syntactic changes the impersonal construction fell out of use between 1450 and 1500 at the latest (Möhlig-Falke 2012: 211). This development may explain why a verb like remembren occurs with a much higher frequency in the reflexive use than in the impersonal construction. Furthermore, if we consider Peitsara's findings given in Figure 1, we may assume that the loss of the impersonal construction happened at a time (in ME4) when the reflexive use considerably increased. What is more, in both ME3 (1350-1420) and ME4 (1420-1500) the strategy to mark the reflexive use with a personal pronoun was much more frequent than the one marked by self (ME3 234/73, ME4 236/92 tokens). The former seems to have been the strategy that came closest to the OF strategy used most frequently (clitic and personal pronoun). Of the set of 96 psych verbs in MED 47 are of French origin, which makes OF influence on the rise of the reflexive use (at least of these verbs) quite likely.

At first sight, my assumptions seem to run counter to Möhlig-Falke's (2012: ch.7.2) observation that for some time in ME the impersonal construction was productively used and even extended to both native and foreign psych verbs, for example to gladen 'to become pleased' or repenten 'to feel regret'. However, if we bring in effects of language contact through translation (see Haeberli 2018, Taylor 2008) we may be able to at least partly explain the increase of the impersonal construction in ME and, what is more, the relation between the reflexive use and the impersonal construction of these verbs. Fortunately, such a comparison is possible since some of the ME texts in the PPCME2 are direct translations of OF texts, for example the Ayenbite of Inwyt (1340, Gradon 1965) which is based on the OF La somme le roi (1279, Brayer and Leurquin-Labie 2008). ${ }^{15}$ Since Dan Michel, the author of the Ayenbite of Inwyt, tends to use native lexemes we may be able to detect how he translated OF psych verbs that were used reflexively. For OF verbs denoting the mental experience of remembering he consistently uses the native verb bithinken. ${ }^{16}$ In (20) a. the reflexive use of OF recorder with the reflexive clitic $m e$ is translated as a reflexive use in $\mathrm{ME}$ with the personal pronoun $m e$ used as reflexive marker. Verbs denoting the mental experience of joy are also found. In b. the OF reflexive verb s'esjoire ${ }^{17}$ 'to gladden' with the reflexive morpheme se is translated as an impersonal construction him gledeth with the native verb gladen, which according to Möhlig-Falke develops this construction only in the impersonal construction (see above). The example in c. shows that a verb expressing the mental experience of regretting like OF repenter with the reflexive clitic marker se is also translated as impersonal construction him uorthingth with the native verb forthinken.

(20) a. aprés, je me recorde souvent aucune chose que je n'ai pas dite; efterwards ich me bethenche ofte of some thinges thet ich ne habbe nagt yzed.

'Afterwards I often remember some things that I haven't said.'

b. de tiex choses s'esjoist il en son cuer.

Of thelliche thinges him gledeth ine his herte.

'Of such things he is glad in his heart.'

(Somme ch. 33, 35)

15 In fact, 35\% of all texts in the PPCME2 are French-based; cf. Trips and Stein 2019.

16 According to the OED remembren is first attested in the early version of the Wycliffite Bible (a1382), but probably not before the text was completed in 1340. This also applies to other verbs of this semantic class like ME recorden. I looked at all OF verbs in the text denoting this mental state and how they are translated by Dan Michel.

17 The OF form is enjoiier and the Anglo-French form esjoir. 
c. mesqui biense repent, il n'endoit paller

Ac he thet him wel uorthingth he ne ssel naght therof yhere speke

'But he who regrets very much he shall not thereof hear speaking.'

(Somme ch. 56, 331)

Comparing the two reflexive systems again, we may assume that the reflexive morpheme se posed the biggest problem to Dan Michel as there was no morphological equivalent available in ME. But since the reflexive use and the impersonal construction shared middle semantics he could resort to use the latter, familiar construction. What may have also helped was that the ME reflected in Dan Michel's writing (late thirteenth century) still allowed preverbal positioning of (object) pronouns (cf. Haeberli 2018: 316), a syntactic property also found in OF. Whether this may have been a favouring factor as well in the increase of reflexive uses needs further investigation.

These few examples illustrate that contact through translation should be taken seriously, especially in quantitative studies where results will otherwise be skewed (see Haeberli 2018: 305) since a considerable number of texts in corpora and lexical resources are based on translations. In the case at hand, the Ayenbite of Inwyt is likely to have increased the reflexive use and the impersonal construction of ME verbs at least in writing (for a discussion of priming effects see e.g. Mahowald et al. 2016).

\section{Conclusion}

This article has examined the relation between reflexive verbs copied from OF and their appearance in the impersonal construction in ME, based on observations first made by van der Gaaf (1904) for the ME psych verb remembren, and commented on in Fischer (1992). Studying the reflexive systems in OF, OE and ME I concluded that $\mathrm{OE}$ and ME speakers/writers were familiar with the argument and non-argument reflexive, just as OF speakers/writers were, which may have been a favouring factor in the copying of OF psych verbs (although the two languages formally expressed reflexivity partly in different ways). Scrutinising and comparing the syntactic and semantic properties of $\mathrm{OF}$ remembrer and ME remembren in a lexicon-based and a corpus-based study, I have shown that the argument structures of this subject-EXPERIENCER verb in both the reflexive and the impersonal construction are intransitive. Following Möhlig-Falke's (2012) cognitive semantic analysis, I have assumed that these two constructions share middle semantics. I have provided further evidence from various corpora and shown that all admire-type psych verbs occurring in the impersonal construction in ME behave just like remembren. Finally I have discussed data that reflect contact through translation and shown that both the reflexive use and the impersonal construction are options in translating the reflexive use of OF verbs. Semantic, morphological and syntactic factors seem to have played a role. Overall, it seems likely that the increasing use of reflexive argument structures expressing middle semantics is a consequence of contact with OF. Occurrences of the impersonal construction, which was lost in a subperiod of ME (1350-1500), may at least partly be seen as translation effects.

Funding: Deutsche Forschungsgemeinschaft, Funder Id: http://dx.doi.org/10.13039/501100001659, Grant Number: TRI 555/6-1, TRI 555/6-2.

\section{References}

Allen, C. L. 1995. Case marking and reanalysis: Grammatical relations from Old to Early Modern English. Oxford: Clarendon Press.

Barðdal, J. 2004. The semantics of the impersonal construction in Icelandic, German, and Faroese: Beyond thematic roles. In W. Abraham (ed.), Topics of germanic typology, 105-137. Berlin: Akademie Verlag.

Blumenthal, P. \& A. Stein (eds.) 2002. Tobler-Lommatzsch: Altfranzösisches Wörterbuch. 4 CD-ROMs und DVD mit Begleitbuch. Stuttgart: Steiner.

Brayer, E. \& A.-F. Leurquin-Labie. 2008. La Somme le Roi par Frère Laurent. Paillart, Paris, Abbeville: Société des Anciens Textes Français.

Buridant, C. 2000. Grammaire Nouvelle de l'Ancien Français. Paris: Sedes. 
Croft, W. 1991. Syntactic categories and grammatical relations: The cognitive organization of information. Chicago: University of Chicago Press.

Denison, D. 1990. The Old English impersonal revived. In S. Adamson, V. Law, N. Vincent \& S. Wright (eds.), Papers from the 5 th international conference on English historical linguistics, 111-140. Amsterdam/Philadelphia: Benjamins.

Einenkel, E. 1916. Geschichte der englischen Sprache, volume II: Historische Syntax. Strasbourg: Trübner.

Fellbaum, C. (ed.) 1998. WordNet: An Electronic Lexical Database. Cambridge, MA: MIT Press.

Fischer, O. 1992. Syntax. In N. Blake (ed.) The Cambridge history of the English language, volume II, 207-408. Cambridge: Cambridge University Press.

Fischer, O. \& F. van der Leek. 1983. The demise of the Old English impersonal construction. Journal of Linguistics 19. $337-368$.

Gradon, P. (ed.) 1965. Dan Michel's Ayenbite of Inwyt or Remorse of Conscience, volume I of The Early English Text Society 278. Oxford: Oxford University Press [reprint of 1866].

Haeberli, E. 2018. Syntactic effects of contact in translations: evidence from object pronoun placement in Middle English. English Language and Linguistics 22(2). 301-321.

Heidinger, S. 2010. French anticausatives. A diachronic perspective. Berlin: de Gruyter.

Johanson, L. 2002. Contact-induced change in a code-copying framework. In M. C. Jones \& E. Esch (eds.) Language change: the interplay of internal, external and extra-linguistic factors, 285-313. Berlin: de Gruyter.

Keenan, E. 2009. Linguistic theory and the historical creation of English reflexives. In P. Crisma \& G. Longobardi (eds.) Historical Syntax and Linguistic Theory, 17-40. Oxford: Oxford University Press.

Kemmer, S. 1993. The middle voice. In Typological Studies in Language, Number 23. Amsterdam and Philadelphia: Benjamins Publishing.

König, E. \& P. Siemund. 2000. The development of complex reflexives and intensifiers in English. Diachronica XVII(1). 39-84.

Langacker, R. 1987. Foundations of Cognitive Grammar. Volume I: Theoretical Prerequisites. Stanford: Stanford University Press.

Levin, B. 1993. English verb classes and alternations. A preliminary investigation. Chicago: University of Chicago Press.

Mahowald, K., A. James, R. Futrell, \& E. Gibson. 2016. A meta-analysis of syntactic priming in language production. Journal of Memory and Language 91. 5-27.

Mathieu, E. 2006. Quirky subjects in Old French. Studia Linguistica 60. 282-312.

McSparran, F., et al. (eds.) 2000-2018. Middle English Dictionary online. Ann Arbor: University of Michigan Library. http:// quod.lib.umich.edu/m/middle-english-dictionary/. Accessed 15 February 2020.

McWhorter, J. 2004. What happened to English? In H. Czepluch \& W. Abraham (eds.) Focus on Germanic typology, number 6 in Studia typologica, 19-60. Berlin: Akademie Verlag.

Möhlig-Falke, R. 2012. The Early English Impersonal Construction. An Analysis of Verbal and constructional meaning. Oxford: Oxford University Press.

Mossé, F. 1991. Handbook of Middle English, 10 edn. Baltimore and London: The Johns Hopkins University Press, reprint of 1952.

Mustanoja, T. F. 1960. A Middle English Syntax Part I. Number 23 in Mémoires de la Société Néophilologique de Helsinki. Société Néophilologique, Helsinki.

OED online. 2008. Oxford English Dictionary online, 2 edn. Oxford: Oxford University Press

Ogura, M. 2003. Reflexive' and 'impersonal' constructions in medieval English. Anglia 121. 535-556.

Peitsara, K. 1997. The development of reflexive strategies in English. In M. Rissanen, M. Kyto \& K. Heikkonen (eds.) Grammaticalization at Work: Studies of Long-Term Developments in English, 277-370. Berlin: Mouton de Gruyter.

Percillier, M. 2018. A toolkit for lemmatising, analysing, and visualising Middle English data. In A. U. Frank, et al. (eds.) Proceedings of the Second Workshop on Corpus-Based Research in the Humanities CRH-2, volume 1, 153-160.

Rissanen, M. \& J. Tyrkkö. 1991. The Helsinki corpus of English texts. Helsinki: Department of Modern Languages, University of Helsinki.

Steinbach, M. 2002. Middle Voice. A comparative study in the syntax-semantics interface of German. Linguistik Aktuell/Linguistics Today 50. Amsterdam and Philadelphia: Benjamins Publishing.

Sweet, H. 1891. A New English grammar. Logical and historical., volume Part I, Introduction, Phonology and Accidence. Oxford: Clarendon.

Taylor, A. 2008. Contact effects of translation: Distinguishing two kinds of influence in Old English. Language Variation and Change 20. 341-365.

Trips, C. \& A. Stein. 2019. Contact-induced changes in the argument structure of Middle English verbs on the model of Old French. In E. Grossman, I. Serzant \& A. Witzlack-Makarevich (eds.) Journal of Language Contact. Special Issue on Valency and Transitivity in Contact, 232-267. Leiden: Brill.

van der Gaaf, W. 1904. The transition from the impersonal to the personal construction in Middle English. Heidelberg: Winter. van Gelderen, E. 2002. A history of the English reflexive pronouns: person, self, interpretability. Amsterdam and Philadelphia: Linguistik Aktuell/Linguistics Today 39. John Benjamins.

van Gelderen, E. 2018. The diachrony of verb meaning. Aspect and argument structure. New York and London: Routledge.

Visser, F. T. 1963. An historical syntax of the English language. Leiden: E. J. Brill.

Waltereit, R. 2012. Reflexive marking in the history of French. Amsterdam and Philadelphia: John Benjamins.

Winford, D. 2003. An Introduction to contact linguistics. Oxford: Blackwell. 